\title{
Influence of Simulated Imazapic and Imazethapyr Herbicide Carryover on Cotton (Gossypium hirsutum L.)
}

\author{
W. James Grichar, ${ }^{1}$ Peter A. Dotray, ${ }^{2}$ and Todd A. Baughman ${ }^{3}$ \\ ${ }^{1}$ Texas AgriLife Research, 3507 Hwy 59E, Beeville, TX 78102, USA \\ ${ }^{2}$ Texas Tech University, Texas AgriLife Research, and Texas AgriLife Extension Service, Lubbock, TX 79403, USA \\ ${ }^{3}$ Texas AgriLife Extension Service, Vernon, TX 76384, USA
}

Correspondence should be addressed to W. James Grichar, w-grichar@tamu.edu

Received 8 September 2011; Accepted 10 October 2011

Academic Editor: David Clay

Copyright ( $) 2012$ W. James Grichar et al. This is an open access article distributed under the Creative Commons Attribution License, which permits unrestricted use, distribution, and reproduction in any medium, provided the original work is properly cited.

\begin{abstract}
Field studies were conducted during the 2001 and 2002 growing seasons in the Texas peanut growing regions to simulate residual concentrations of imazapic and imazethapyr in the soil and subsequent effects on cotton (Gossypium hirsutum L.). Simulated imazapic or imazethapyr rates included $0,1 / 64 \mathrm{X}$ (1.09 g ai/ha), 1/32X (2.19g ai/ha), 1/16X (4.38 g ai/ha), 1/8X (8.75 g ai/ha), 1/4X ( $17.5 \mathrm{~g}$ ai/ha), and 1/2X (35 g ai/ha) of the full labeled rate for peanut (Arachis hypogaea L.) and incorporated prior to cotton planting. Cotton stunting with imazapic or imazethapyr was more severe at Denver City than other locations. All rates of imazapic and imazethapyr resulted in cotton stunting at Denver City while at Munday and Yoakum the 1/8X, 1/4X, and 1/2X rates of imazapic resulted in reduced cotton growth when compared with the untreated check. At all locations imazapic caused more stunted cotton than imazethapyr. Cotton lint yield was reduced by imazapic or imazethapyr at $1 / 4 \mathrm{X}$ and $1 / 2 \mathrm{X}$ rates at all locations when compared with the untreated check.
\end{abstract}

\section{Introduction}

Imazethapyr and imazapic are imidazolinone herbicides registered for use in peanut (Arachis hypogaea L.) and are used extensively in the various peanut growing regions of Texas. Imazethapyr may be applied preplant incorporated (PPI), preemergence (PRE), ground cracking (GC), or postemergence (POST) for effective weed control [1]. Imazethapyr applied PPI or PRE controls many troublesome weeds such as coffee senna (Cassia occidentalis L.), common lambsquarter (Chenopodium album L.), morningglory species (Ipomoea spp.), pigweed species (Amaranthus spp.) including Palmer amaranth (Amaranthus palmeri S. Wats), prickly sida (Sida spinosa L.), purple and yellow nutsedge (Cyperus rotundus L. and C. esculentus L., resp.), spurred anoda [Anoda cristata (L.) Schlecht.], and wild poinsettia (Euphorbia heterophylla L.) $[2-6]$.

Imazethapyr applied POST provides broad spectrum and most consistent control when applied within $10 \mathrm{~d}$ of weed emergence [3, 7-9]. Imazethapyr and imazapic are the only POST herbicides to effectively control both yellow and purple nutsedge $[5,10]$. Control is most effective when imazethapyr is applied to the soil or to yellow nutsedge that is no more than $13 \mathrm{~cm}$ tall $[1,10,11]$.

Imazapic is similar to imazethapyr and controls all the weeds controlled by imazethapyr [1, 9, 12-14]. In addition, imazapic provides control or suppression of Florida beggarweed [Desmodium tortuosum (S.W.) D.C.] and sicklepod [Senna obtusifolia (L.) Irwin and Barneby], which are not adequately controlled by imazethapyr [15]. Imazethapyr provides consistent control of many broadleaf and sedge species if applied within $10 \mathrm{~d}$ after emergence, but imazapic has a longer effectiveness period when applied POST $[1,10$, $14,16]$. Imazapic also is effective for control of rhizome and seedling johnsongrass [Sorghum halepense (L.) Pers.], Texas millet [Urochloa texana (Buckl.) R. Webster], large crabgrass [Digitaria sanguinalis (L.) Scop.], southern crabgrass [Digitaria ciliaris (Retz.) Koel.], and broadleaf signalgrass [Brachiaria platyphylla (Griseb.) Nash] [14].

In crop rotations, the imidazolinone herbicides must be used with caution. Monks and Banks [17] observed slight corn (Zea mays L.) injury and severe cotton injury from 
imazaquin (another imidazolinone herbicide) applied to soybean [Glycine max (L.) Merr.] the previous year. Renner et al. [18] observed significant corn injury from imazaquin applied the previous year in one of two years. In Arkansas, cotton yield was reduced 7 to $42 \%$ as the soil concentration of imazaquin increased from 7.5 to $26 \mathrm{~g}$ ai/ha [19]. Imazethapyr has been observed to moderately injure corn [20]. Johnson et al. [21] reported slight but significant injury to rice (Oryza sativa L.) from imazethapyr applied to soybean the previous year. Rotational crops such as sugarbeet (Beta vulgaris L.), canola (Brassica napus L.), cauliflower (Brassica oleracea L.), broccoli (Brassica oleracea L.), and lettuce (Lactuca sativa L.) may also be damaged when planted following imazethapyr $[22,23]$.

Previous research on imazapic carryover has shown varying results. In North Carolina, imazapic applied PPI at $35 \mathrm{~g}$ ai/ha reduced cotton yield $43 \%$ the following year while imazapic at the same rate applied at emergence caused 20\% cotton injury but no yield reduction the following season [24]. In Georgia, imazapic at $35 \mathrm{~g}$ ai/ha reduced cotton yield an average of $34 \%$ the year following application regardless of application method [24].

A Mississippi study indicated no reduction in shoot weight when corn, grain sorghum [Sorghum bicolor (L.) Moench], cotton, rice, wheat (Triticum aestivum L.), soybean, and Italian ryegrass (Lolium multiflorum L.) were planted directly into soil treated and incorporated with imazapic at rates up to $35 \mathrm{~g}$ ai/ha [25]. In that study, all crops were more sensitive in the greenhouse with rates of $11.6 \mathrm{~g}$ ai/ha reducing corn and grain sorghum shoot weights. However, cotton, rice, and wheat tolerated rates of 19 to $38 \mathrm{~g}$ ai/ha. Grymes et al. [26] reported that imazapic at $69 \mathrm{~g}$ ai/ha or imazapic plus imazethapyr each at $35 \mathrm{~g}$ ai/ha reduced rice yield the year following application. Grymes et al. [26] felt that imazapic injury to rice grown in rotation with soybean may be reduced by implementing a later rice planting date. They hypothesized that the later date allowed time for more herbicide degradation in the soil. Also, herbicide metabolism by the rice plant may be greater at the later planting date due to warmer temperatures [26].

The persistence of the imidazolinones in soil is influenced by the degree of adsorption to soil, soil moisture content, temperature, and amount of exposure to sunlight [27-29]. The degree of soil adsorption increases as organic matter content increases and $\mathrm{pH}$ decreases [30,31].

The primary mode of herbicidal decomposition is by microbial degradation, and degradation is most rapid in soils with temperatures and moisture contents that favor microbial activity [32, 33]. Photodecomposition accounts for a small amount of imidazolinone degradation when the herbicide is on the soil surface but rainfall or incorporation removes the herbicide from exposure to light $[32,34]$.

Above soil $\mathrm{pH} 4.0$, the carboxyl groups on imazethapyr dissociate, and soil adsorption of the resulting herbicide anion is negligible [29]. However, in the presence of clay at $\mathrm{pH} 5.0$, fluorescence emission spectra indicate that imazethapyr is adsorbed in the neutral form [30]. At $\mathrm{pH} 8.0$, only the ionized form was observed even in the presence of clay. Increased adsorption and persistence were observed as the $\mathrm{pH}$ decreased from 6.5 to 4.5 [33]. Injury to crops seeded following imidazolinone herbicide application also increased as soil pH decreased from 7.7 to 6.0 [35]. This indicated that increased adsorption did not protect crops from imidazolinone herbicide residue at $\mathrm{pH}$ 6.0.

Most peanut soils in south and central Texas have a $\mathrm{pH}$ of 6.5 to 7.5 and organic matter content $\leq 1 \%$. Therefore, in these soils, imidazolinone herbicides are readily available for microbial degradation. However, in the Texas High Plains, the $\mathrm{pH}$ may range from 7.0 to 8.5 resulting in reduced microbial degradation. With soils low in organic matter and near neutral $\mathrm{pH}$, little imidazolinone herbicide should be adsorbed onto soil particles. Crops with low tolerance to the imidazolinone herbicides such as cotton are grown in rotation with peanut in many areas of Texas where imazethapyr or imazapic may be used. Evaluating imazethapyr or imazapic in the different regions will provide a more relevant understanding of the persistence issue. Therefore, the objective of this research was to evaluate cotton tolerance to imazethapyr and imazapic concentrations when planted at several locations in the peanut growing areas of Texas.

\section{Materials and Methods}

Field studies were conducted in Knox County (Munday), Lavaca County (Yoakum), and Yoakum County (Denver City), Texas during the 2001 and 2002 growing seasons to evaluate cotton response to sublabeled imazapic and imazethapyr rates to simulate carryover. Soil characteristics are presented in Table 1. The soils selected are representative of the soils found in different areas of Texas where a peanutcotton rotation may be found.

The experimental design was a randomized complete block with a factorial arrangement of two herbicide treatments and seven rates with four replications. One factor was herbicide which included imazapic (Cadre, BASF Corporation, P.O. Box 13528, Research Triangle Park, NC 27709) and imazethapyr (Pursuit, BASF Corporation). The other factor was herbicide rate applied at $0,1.09 \mathrm{~g}$ ai/ha $(1 / 64 \mathrm{X})$, $2.19 \mathrm{~g}$ ai/ha (1/32X), $4.38 \mathrm{~g}$ ai/ha (1/16X), $8.75 \mathrm{~g}$ ai/ha (1/8X), $17.5 \mathrm{~g}$ ai/ha $(1 / 4 \mathrm{X})$, and $35 \mathrm{~g}$ ai/ha $(1 / 2 \mathrm{X})$. These rates were chosen as a representation of the dissipation of imazapic and imazethapyr over time with respect to estimated dissipation time. The normal use rate of imazapic and imazethapyr in peanut is $69 \mathrm{~g}$ ai/ha with a half-life of $120 \mathrm{~d}$ [36].

Herbicides at the Yoakum location were applied with a $\mathrm{CO}_{2}$ pressurized backpack sprayer equipped with Teejet 11002 DG flat fan spray tips (Spraying Systems Company, P.O. Box 7900, North Avenue, Wheaton, IL 60188) which delivered a spray volume of $190 \mathrm{~L} / \mathrm{ha}$ at $180 \mathrm{kPa}$. At the Denver City location, herbicides were applied with a $\mathrm{CO}_{2}$ pressurized backpack sprayer using Teejet 110015 TT flat fan spray tips calibrated to deliver a spray volume of $94 \mathrm{~L} / \mathrm{ha}$ at $207 \mathrm{kPa}$. At the Munday location, herbicides were applied with a $\mathrm{CO}_{2}$ pressurized backpack sprayer equipped with Teejet 110015 AI flat fan spray tips which delivered 94 $\mathrm{L} / \mathrm{ha}$ at $180 \mathrm{kPa}$. After application, herbicides at Yoakum were incorporated approximately 5 to $6 \mathrm{~cm}$ deep with a tractor-driven power tiller while at the Denver City location, 
TABLE 1: Cotton varieties, planting dates, and soil characteristics of each site.

\begin{tabular}{|c|c|c|c|c|c|}
\hline \multirow[b]{2}{*}{ Variables } & \multicolumn{3}{|c|}{2001} & \multicolumn{2}{|c|}{2002} \\
\hline & Denver City & Munday & Yoakum & Denver City & Yoakum \\
\hline Herbicides applied & April 26 & May 8 & April 27 & April 18 & April 23 \\
\hline Planting date & May 18 & May 8 & April 27 & June 3 & April 23 \\
\hline Soil texture & LFS & FSL & SL & LFS & SL \\
\hline Soil name & Brownfield & Miles & Hallettsville & Brownfield & Hallettsville \\
\hline $\mathrm{pH}$ & 7.6 & 8.1 & 6.8 & 7.6 & 7.2 \\
\hline $\mathrm{OM}(\%)$ & $<1.0$ & 0.1 & 1.2 & $<1.0$ & 1.0 \\
\hline Sand (\%) & 80 & 75 & 65 & 80 & 65 \\
\hline Silt (\%) & 3 & 16 & 18 & 3 & 17 \\
\hline Clay (\%) & 17 & 9 & 17 & 17 & 18 \\
\hline Cotton variety & PM1218RR & PM1218RR & ST 4793RR & PM 2280RR & SG 215RR \\
\hline
\end{tabular}

a Abbreviations: FSL: fine sandy loam; LFS: loamy fine sand; SL: sandy loam; OM: organic matter.

herbicides were incorporated into the soil using a tandem disk set to incorporate 10 to $15 \mathrm{~cm}$ deep. At the Munday location, herbicides were applied and incorporated twice 2.5 to $5 \mathrm{~cm}$ deep with a rolling cultivator. Cotton was planted at Yoakum and Munday within $24 \mathrm{~h}$ of herbicide incorporation while at Denver City herbicides were applied approximately 6 wk prior to cotton planting. At Yoakum, each plot contained two rows, $91 \mathrm{~cm}$ apart and $7.9 \mathrm{~m}$ long while at Denver City and Munday each plot contained four rows spaced $102 \mathrm{~cm}$ apart and $9.5 \mathrm{~m}$ long. All plots were maintained weedfree using standard herbicides recommended by the Texas AgriLife Extension Service.

Visual estimates of crop stunting were determined 7 to 9 wk after cotton planting using a scale of 0 to 100 , where 0 equals no crop stunting and 100 equals complete crop death. Cotton was either hand-picked or mechanically harvested using commercial harvesting equipment modified for plot harvest. Data were analyzed using the general linear models and means separated using Fisher's protected LSD at $P<$ 0.05 .

\section{Results and Discussion}

3.1. Cotton Emergence. No stand reduction was noted with any rate of imazethapyr or imazapic at any location (data not shown). In previous work in Texas, Matocha et al. [37] reported that cotton stand was not affected by imazapic applied at rates up to $144 \mathrm{~g}$ ai/ha the previous season. Wixson and Shaw [25] reported that imazapic did not reduce the emergence of cotton with rates up to $35 \mathrm{~g}$ ai/ha on a silty clay soil with $\mathrm{pH}$ of 7.2 and $3.2 \%$ organic matter while Walsh et al. [38] found that imazethapyr at 48 to $96 \mathrm{~g}$ ai/ha did not cause a loss of cotton stand. Wiatrak et al. [39] noted that imazapic at the $1 \mathrm{X}$ rate $(70 \mathrm{~g}$ ai/ha) reduced cotton stand in one of two years in Florida while Grey et al. [40] reported no stand reduction at Tifton, GA on a loamy sand with $\mathrm{pH}$ of 6.0 and $1.3 \%$ organic matter. However, at Plains, GA on a sandy loam with $\mathrm{pH}$ of 5.8 to 6.0 and $1.0 \%$ organic matter, cotton plants emerged at all imazethapyr and imazapic rates, but by 14 days after treatment (DAT), cotton began to die with sporadic plants exhibiting distended growth. Similar effects were seen in cotton with imazaquin carryover at $70 \mathrm{~g}$ ai/ha in Arkansas [41]. None of these effects were observed at any of the Texas locations.

3.2. Cotton Injury and Stunting. Cotton injury observed at all locations included malformation and chlorosis of leaf tissue and plant stunting, typical of imidazolinone herbicides [19, $42,43]$. There was a herbicide, rate, and location interaction; therefore, data are presented individually by herbicide rate and location.

2001. Stunting with imazapic and/or imazethapyr was more severe at Denver City than the other locations (Table 2). At Denver City, imazapic at $1 / 16$ to $1 / 2 \mathrm{X}$ resulted in 81 to $100 \%$ cotton stunting while imazethapyr at $1 / 16$ to $1 / 2 \mathrm{X}$ resulted in 60 to $100 \%$ cotton stunting. At all rates, with the exception of the $1 / 64$ and $1 / 2 \mathrm{X}$ rates, imazethapyr was less injurious to cotton than imazapic.

At Munday, the high rate of imazapic and imazethapyr caused 48 and 16\% cotton stunting, respectively. No significant stunting was observed at Munday with imazapic rates $1 / 16 \mathrm{X}$ or lower or imazethapyr rates $1 / 4 \mathrm{X}$ or lower. The $1 / 4 \mathrm{X}$ rate of imazapic resulted in over $20 \%$ cotton stunting.

At Yoakum, cotton stunting was at least $45 \%$ when the rate of either imazapic or imazethapyr was $1 / 4 \mathrm{X}$ or greater (Table 2). Although imazapic at 1/8X rate caused $15 \%$ stunting, only $4 \%$ cotton stunting was noted with the same rate of imazethapyr. None of the other rates of imazapic or imazethapyr resulted in cotton stunting that was different from the untreated check.

2002. At Denver City, all rates of imazapic or imazethapyr resulted in at least $32 \%$ cotton stunting (Table 2). No difference in cotton stunting was noted between imazapic and imazethapyr. The highest applied rate of $35 \mathrm{~g}$ ai/ha $(1 / 2 \mathrm{X})$ of imazapic or imazethapyr resulted in at least $85 \%$ cotton stunting.

At Yoakum, imazapic caused no greater than $18 \%$ cotton stunting while imazethapyr resulted in $8 \%$ or less cotton stunting at all rates (Table 2). The $1 / 4$ and $1 / 2 \mathrm{X}$ rates of imazapic were the only treatments that resulted in cotton stunting that was different from the untreated check. Rainfalls for May, June, July, August, and September were 33, 
TABLE 2: Cotton stunting as affected by simulated rates of imazapic and imazethapyr. ${ }^{\text {a }}$

\begin{tabular}{|c|c|c|c|c|c|c|}
\hline \multirow[b]{2}{*}{ Herbicide } & \multirow[b]{2}{*}{ Rate $^{\mathrm{b}}$} & \multicolumn{3}{|c|}{2001} & \multicolumn{2}{|c|}{2002} \\
\hline & & Denver City & Munday & Yoakum & Denver City & Yoakum \\
\hline & \multicolumn{6}{|c|}{$\%$} \\
\hline Untreated & 一 & 0 & 0 & 0 & 0 & 0 \\
\hline \multirow{6}{*}{ Imazapic } & $1 / 64 X$ & 14 & 0 & 3 & 37 & 6 \\
\hline & $1 / 32 X$ & 48 & 3 & 0 & 43 & 3 \\
\hline & $1 / 16 \mathrm{X}$ & 81 & 4 & 8 & 54 & 10 \\
\hline & $1 / 8 \mathrm{X}$ & 84 & 8 & 15 & 54 & 13 \\
\hline & $1 / 4 \mathrm{X}$ & 98 & 23 & 62 & 73 & 18 \\
\hline & $1 / 2 \mathrm{X}$ & 100 & 48 & 75 & 85 & 15 \\
\hline \multirow{6}{*}{ Imazethapyr } & $1 / 64 X$ & 8 & 0 & 3 & 32 & 8 \\
\hline & $1 / 32 X$ & 17 & 3 & 0 & 33 & 8 \\
\hline & $1 / 16 \mathrm{X}$ & 60 & 1 & 0 & 53 & 5 \\
\hline & $1 / 8 \mathrm{X}$ & 70 & 1 & 4 & 64 & 4 \\
\hline & $1 / 4 \mathrm{X}$ & 89 & 6 & 45 & 77 & 3 \\
\hline & $1 / 2 X$ & 100 & 16 & 53 & 89 & 4 \\
\hline LSD (0.05) & & 9 & 7 & 14 & 15 & 13 \\
\hline
\end{tabular}

${ }^{a}$ Stunting ratings taken 7 weeks after herbicide application at Yoakum in 2001; 8 weeks after herbicide application at Denver City in 2001, Munday, and Yoakum in 2002; 9 weeks after herbicide application at Denver City in 2002.

${ }^{b}$ Herbicide rate: $1.09 \mathrm{~g}$ ai/ha (1/64X), $2.19 \mathrm{~g}$ ai/ha (1/32X), $4.38 \mathrm{~g}$ ai/ha (1/16X), $8.75 \mathrm{~g}$ ai/ha (1/8X), $17.5 \mathrm{~g}$ ai/ha (1/4X), and $35 \mathrm{~g}$ ai/ha (1/2X).

TABLE 3: Cotton lint yield as affected by simulated rates of imazapic and imazethapyr.

\begin{tabular}{|c|c|c|c|c|c|c|}
\hline \multirow[b]{2}{*}{ Herbicide } & \multirow[b]{2}{*}{ Rate $^{\mathrm{a}}$} & \multicolumn{3}{|c|}{2001} & \multicolumn{2}{|c|}{2002} \\
\hline & & Denver City & Munday & Yoakum & Denver City & Yoakum \\
\hline & & \multicolumn{5}{|c|}{$\mathrm{Kg} / \mathrm{ha}$} \\
\hline Untreated & - & 1080 & 1800 & 925 & 830 & 1455 \\
\hline \multirow{6}{*}{ Imazapic } & $1 / 64 \mathrm{X}$ & 1205 & 1905 & 995 & 860 & 1565 \\
\hline & $1 / 32 \mathrm{X}$ & 1050 & 1630 & 1210 & 910 & 1690 \\
\hline & $1 / 16 \mathrm{X}$ & 800 & 1920 & 700 & 975 & 1425 \\
\hline & $1 / 8 \mathrm{X}$ & 785 & 1845 & 845 & 1020 & 1350 \\
\hline & $1 / 4 \mathrm{X}$ & 195 & 1615 & 275 & 805 & 1040 \\
\hline & $1 / 2 \mathrm{X}$ & 0 & 1645 & 100 & 400 & 1385 \\
\hline \multirow{6}{*}{ Imazethapyr } & $1 / 64 \mathrm{X}$ & 1195 & 1890 & 935 & 955 & 1635 \\
\hline & $1 / 32 X$ & 1160 & 1660 & 1180 & 885 & 1310 \\
\hline & $1 / 16 \mathrm{X}$ & 1073 & 1720 & 1220 & 1100 & 1690 \\
\hline & $1 / 8 \mathrm{X}$ & 830 & 1685 & 895 & 975 & 1675 \\
\hline & $1 / 4 \mathrm{X}$ & 485 & 1600 & 435 & 780 & 1645 \\
\hline & $1 / 2 \mathrm{X}$ & 100 & 1685 & 375 & 700 & 1740 \\
\hline LSD (0.05) & & 280 & NS & 370 & 310 & 535 \\
\hline
\end{tabular}

${ }^{a}$ Herbicide rate: $1.09 \mathrm{~g}$ ai/ha (1/64X), $2.19 \mathrm{~g}$ ai/ha (1/32X), $4.38 \mathrm{~g}$ ai/ha (1/16X), $8.75 \mathrm{~g}$ ai/ha (1/8X), $17.5 \mathrm{~g}$ ai/ha (1/4X), and $35 \mathrm{~g}$ ai/ha (1/2X).

$114,136,106$, and $114 \mathrm{~mm}$, respectively. Normal rainfalls for these months are $112,109,66,79$, and $102 \mathrm{~mm}$, respectively. The above normal rainfall for July and August may have accounted for the lack of cotton response to imazapic and imazethapyr. Microbial degradation is the primary degradation mechanism of imidazolinones and is accentuated by warm, moist soil conditions [44]. In contrast, dry conditions can prolong carryover effects of these herbicides [44]. Wixson and Shaw [25] reported that in soils with a $\mathrm{pH} 7.2$ and $3.2 \%$ organic matter, corn and cotton tolerated imazapic up to $35 \mathrm{~g}$ ai/ha. Crop injury was observed with imazethapyr in both crops at rates from 5.5 to $17 \mathrm{~g}$ ai/ha. The authors indicated that the injury noted with low rates of imazethapyr could be related to the increase of adsorption of the imidazoline herbicides with increasing organic matter content. Wiatrek et al. [39] reported that cotton height was reduced with the high rates of imazapic in one year but not another. Grey et al. [40] reported a negative exponential trend where 
cotton height decreased as imazapic rate increased. Matocha et al. [37] reported a reduction in cotton height with imazapic applied at 140 and $210 \mathrm{~g}$ ai/ha the previous year.

3.3. Cotton lint Yield. There was a herbicide (imazapic and imazethapyr), rate, and location interaction; therefore, data are presented separately by herbicide, rate, and location.

2001. Lint yields at Denver City were reduced following the $1 / 8 \mathrm{X}, 1 / 4 \mathrm{X}$, and $1 / 2 \mathrm{X}$ rates of imazethapyr or imazapic (Table 3$)$. No cotton was produced from plots treated with imazapic at the $1 / 2 \mathrm{X}$ rate while imazethapyr at the $1 / 2 \mathrm{X}$ rate produced cotton yield that was $8 \%$ of the untreated check.

At Munday, none of the herbicide treatments reduced cotton yield when compared with the untreated check. An explanation for the lack of yield differences may be due to soil characteristics. The other locations all had a clay content of at least $17 \%$ while this site had a clay content of less than $10 \%$. The $\mathrm{pH}$ at the Munday site was 8.1 which was greater than the $\mathrm{pH}$ values of 7.6 or less at the other locations (Table 1). Imazapic is weakly adsorbed in high $\mathrm{pH}$ soils and adsorption increases as the $\mathrm{pH}$ decreases and with increasing clay and organic matter content [19, 37, 40, 42, 45]. At Yoakum, cotton lint yields were reduced by the $1 / 4 \mathrm{X}$ and $1 / 2 \mathrm{X}$ rates of imazapic and imazethapyr (Table 3 ). Imazapic at the $1 / 16 \mathrm{X}$ rate resulted in lower yields than imazethapyr at the $1 / 16$ or imazapic and imazethapyr at the $1 / 32 \mathrm{X}$ rates.

2002. At Denver City, only the $1 / 2 \mathrm{X}$ rate of imazapic resulted in lower cotton yields than the untreated check (Table 3). No negative response was noted with any of the imazethapyr treatments.

At Yoakum, no reduction in cotton yield was noted when the untreated check was compared with any imazapic or imazethapyr treatments (Table 3 ). However, plots which received imazethapyr, with the exception of the $1 / 32 \mathrm{X}$ rate, produced higher yields than those that received $1 / 4 \mathrm{X}$ rate of imazapic. The above average rainfall amounts for July and August may help explain a lack of yield reduction observed with the higher rates of imazapic and imazethapyr. The imidazolinones are soluble in water and are not degraded hydrolytically in aqueous solution [34]. However, in water, these herbicides are rapidly photodegraded by sunlight with a half-life of one to two days $[29,34]$.

Previous research on imazapic carryover has shown varying results. In North Carolina, imazapic applied PPI to peanut at $36 \mathrm{~g}$ ai/ha reduced cotton yield $43 \%$ the following year while the same rate of imazapic applied at peanut ground cracking resulted in $20 \%$ injury but no yield reduction [24]. In Georgia, imazapic at $36 \mathrm{~g}$ ai/ha reduced cotton yield an average of $34 \%$ the following year regardless of application timing [24]. Grey et al. [40] also reported that there were no detectable differences in cotton variety response to the imidazolinone herbicides.

\section{Conclusion}

Although different cotton cultivars were used in this study over locations and years, no previous work could be found that reported differential response of cotton cultivars to any of the imidazolinone herbicides. Cotton stunting did not always result in reduced yield, and this may be the result of soil characteristics. However, when stunting was greater than $50 \%$ there was almost always a decrease in cotton yield when compared with the untreated check. This study reveals that several factors are involved in the persistence of imazethapyr and imazapic in the soil and helps to explain the various results observed under varying conditions. By possibly knowing the level of imazapic or imazethapyr residual in the soil, producers could have some flexibility in crop rotations if sensitive crops such as cotton are to be planted following imidazolinone use on peanut.

\section{References}

[1] J. W. Wilcut, A. C. York, W. J. Grichar, and G. R. Wehtje, "The biology and management of weeds in peanut (Arachis hypogaea)," in Advances in Peanut Science, H. E. Pattee and H. T. Stalker, Eds., pp. 207-244, American Peanut Research Education Society, Stillwater, OK, USA, 1995.

[2] T. A. Cole, G. R. Wehtje, J. W. Wilcut, and T. V. Hicks, "Behavior of imazethapyr in soybeans (Glycine max), peanuts (Arachis hypogaea), and selected weeds," Weed Science, vol. 37, pp. 639-644, 1989.

[3] J. W. Wilcut, F. R. Walls Jr., and D. N. Norton, "Imazethapyr for broadleaf weed control in peanuts (Arachis hypogaea)," Peanut Science, vol. 18, pp. 26-30, 1991.

[4] J. W. Wilcut, F. R. Walls Jr., and D. N. Norton, "Weed control, yield, and net returns using imazethapyr in peanuts (Arachis hypogaea)," Weed Science, vol. 39, pp. 238-242, 1991.

[5] W. J. Grichar and P. R. Nester, "Nutsedge (Cyperus spp.) control in peanut (Arachis hypogaea) with imazethapyr," Weed Technology, vol. 6, pp. 396-400, 1992.

[6] A. C. York, J. W. Wilcut, C. W. Swann, D. L. Jordan, and F. R. Walls, "Efficacy of imazethapyr in peanut (Arachis hypogaea) as affected by time of application," Weed Science, vol. 43, pp. 107-116, 1995.

[7] T. L. Grey, G. R. Wehtje, R. H. Walker, and K. P. Paudel, "Comparison of imazethapyr and paraquat-based weed control systems in peanut," Weed Technology, vol. 9, pp. 813-818, 1995.

[8] J. W. Wilcut, J. S. Richburg, E. F. Eastin, G. R. Wiley, F. R. Walls Jr., and S. Newell, "Imazethapyr and paraquat systems for weed management in peanut (Arachis hypogaea)," Weed Science, vol. 42, pp. 601-607, 1994.

[9] J. W. Wilcut, J. S. Richburg III., G. Wiley et al., "Imidazolinone herbicide systems for peanut (Arachis hypogaea)," Peanut Science, vol. 21, pp. 23-28, 1994.

[10] J. S. Richburg III., J. W. Wilcut, and G. R. Wehtje, “Toxicity of foliar and/or soil applied AC 263,222 to purple (Cyperus rotundus) and yellow nutsedge (C. esculentus)," Weed Science, vol. 42, pp. 398-402, 1993.

[11] J. W. Wilcut, J. W. A. C. York, and G. R. Wehtje, "The control and interaction of weeds in peanut (Arachis hypogaea)," Review Weed Science, vol. 6, pp. 177-205, 1994.

[12] P. R. Nester and W. J. Grichar, "Cadre combinations for broadleaf weeds control in peanut," in Proceedings of the Southern Weed Science Society, vol. 46, p. 317, 1993.

[13] W. J. Grichar, A. E. Colburn, and P. R. Nester, "Weed control in Texas peanut with Cadre," in Proceedings of the American Peanut Research and Education Society, vol. 26, p. 70, 1994.

[14] J. W. Wilcut, E. F. Eastin, J. S. Richburg III. et al., "Imidazolinone systems for southern weed management in resistant corn," Weed Science Society America, vol. 33, p. 5, 19933 
[15] T. L. Grey, D. C. Bridges, E. F. Eastin et al., "Residual weed control for peanut (Arachis hypogaea) with imazapic, diclosulam, flumioxazin, and sulfentrazone in Alabama, Georgia, and Florida: a multi-state and year summary," in Proceedings of the American Peanut Research and Education Society, vol. 33, p. 19, 2001.

[16] J. S. Richburg, J. W. Wilcut, D. L. Colvin, and G. R. Wiley, "Weed management in southeastern peanut (Arachis hypogaea) with AC 263,222," Weed Technology, vol. 10, pp. 145152, 1996.

[17] C. D. Monks and P. A. Banks, "Rotational crop response to chlorimuron, clomazone, and imazaquin applied the previous year," Weed Science, vol. 39, pp. 629-633, 1991.

[18] K. A. Renner, W. F. Meggitt, and D. Penner, "Response of corn (Zea mays) cultivars to imazaquin," Weed Science, vol. 36, pp. 625-628, 1988.

[19] C. J. Barnes, A. J. Goetz, and T. L. Lavy, "Effects of imazaquin residues on cotton (Gossypium hirsutum)," Weed Science, vol. 37, pp. 820-824, 1989.

[20] J. A. Mills and W. W. Witt, "Efficacy, phytotoxicity, and persistence of imazaquin, imazethapyr, and clomazone in notill double-crop soybeans (Glycine max)," Weed Science, vol. 37, pp. 353-359, 1989.

[21] D. H. Johnson, R. E. Talbert, J. D. Beaty, C. B. Guy, and R. J. Smith, "Rice response following imazaquin, imazethapyr, chlorimurion, and clomazone use," in Proceedings of the Southern Weed Science Society, vol. 45, p. 371, 1992.

[22] S. D. Miller and H. P. Alley, "Weed control and rotational crop response with AC 222,293," Weed Technology, vol. 1, pp. 29-33, 1987.

[23] B. R. Tickes and K. Umeda, "The effect of imazethapyr upon crops grown in. rotation with alfalfa," in Proceedings of the Society Western Weed Science, vol. 44, p. 97, 1991.

[24] A. C. York and J. W. Wilcut, "Potential for Cadre and Pursuit applied to peanuts to carryover to cotton in North Carolina and Georgia," in Proceedings of the Beltwide Cotton Conference, vol. 1, p. 602, 1995.

[25] M. B. Wixson and D. R. Shaw, "Effects of soil-applied AC 263,222 on crops rotated with soybean (Glycine max)," Weed Technology, vol. 6, pp. 276-279, 1992.

[26] C. F. Grymes, J. M. Chandler, and P. R. Nester, "Response of soybean (Glycine max) and rice (Oryza sativa) in rotation to AC 263,222," Weed Technology, vol. 9, pp. 504-511, 1995.

[27] R. Allen and J. C. Casely, "The persistence and mobility of AC 222,293 in cropped and fallow land," in Proceedings of the British Crop Protection Conference, pp. 569-576, 1987.

[28] N. D. Malik, E. Cole, A. L. Darwent, and J. R. Moyer, "Imazethapyr (Pursuit) - a promising new herbicide for forage legumes," Forage Notes, vol. 32, pp. 42-45, 1988.

[29] G. Mangels, "Behavior of the imidazolinone herbicide in soil-a review of the Literature," in The Imidazolinone Herbicides, D. L. Shaner and S. L. O’Connor, Eds., pp. 191-209, CRC Press, Boca Raton, FL, USA, 1991.

[30] M. Che, M. M. Loux, S. J. Traina, and T. J. Logan, "Effect of pH on sorption and desorption of imazaquin and imazethapyr on clays and humic acid," Journal of Environmental Quality, vol. 21, pp. 698-703, 1992.

[31] M. M. Loux, R. A. Liebl, and F. W. Slife, "Adsorption of imazaquin and imazethapyr on soils, sediments, and selected adsorbents," Weed Science, vol. 37, pp. 712-718, 1989.

[32] A. J. Goetz, T. L. Lavy, and E. E. Gbur, "Degradation and field persistence of imazethapyr," Weed Science, vol. 38, pp. 421428, 1990.
[33] M. M. Loux and K. D. Reese, "Effect of soil type and pH on persistence and carryover of imidazolinone herbicides," Weed Technology, vol. 7, pp. 452-458, 1993.

[34] W. S. Curran, M. M. Loux, R. A. Liebl, and F. W. Simmons, "Photolysis of imidazolinone herbicides in aqueous solutions and on soil," Weed Science, vol. 40, pp. 143-148, 1992.

[35] G. M. Fellows, P. K. Kay, G. R. Carlson, and V. R. Stewart, "Effect of AC 222,293 soil residues on rotational crops," Weed Technology, vol. 4, pp. 48-51, 1990.

[36] S. A. Senseman, Herbicide Handbook, Weed Science Society of America, Lawrence, KA, 9th edition, 2007.

[37] M. A. Matocha, W. J. Grichar, S. A. Senseman, C. A. Gerngross, B. J. Brecke, and W. K. Vencill, "The persistence of imazapic in peanut (Arachis hypogaea) crop rotations," Weed Technology, vol. 17, pp. 325-329, 2003.

[38] J. D. Walsh, M. S. Defelice, and B. D. Sims, "Soybean (Glycine max) herbicide carryover to grain and fiber crops," Weed Technology, vol. 7, pp. 625-632, 1993.

[39] P. J. Wiatrak, D. L. Wright, and J. J. Marois, "Influence of imazapic herbicide simulated carryover on cotton growth, yields, and lint quality," Crop Management. In press.

[40] T. L. Grey, E. P. Prostko, C. W. Bednarz, and J. W. Davis, "Cotton (Gossypium hirsutum) response to simulated imazapic residues," Weed Technology, vol. 19, pp. 1045-1049, 2005.

[41] G. W. Basham, T. L. Lavy, L. R. Oliver, and H. D. Scott, "Imazaquin persistence and mobility in three Arkansas soils," Weed Science, vol. 35, pp. 576-582, 1987.

[42] D. H. Johnson, R. E. Talbert, and D. R. Horton, "Carryover potential of imazaquin to cotton, grain sorghum, wheat, rice, and corn," Weed Science, vol. 43, pp. 454-460, 1995.

[43] A. C. York, D. L. Jordan, R. B. Batts, and A. S. Culpepper, "Cotton response to imazapic and imazethapyr applied to a preceding peanut crop," Journal of Cotton Science, vol. 4, pp. 210-216, 2000.

[44] D. L. Shaner and S. L. O'Connor, "Behavior of the imidazolinone herbicides in the soil-a review of the literature," in The Imidazolinone Herbicides, pp. 191-209, CRC Press, Boca Raton, FL, USA, 1991.

[45] R. N. Stougaard, P. J. Shea, and A. R. Martin, "Effect of soil type and $\mathrm{pH}$ on absorption, mobility, and efficacy of imazaquin and imazethapyr," Weed Science, vol. 38, pp. 67-73, 1990. 


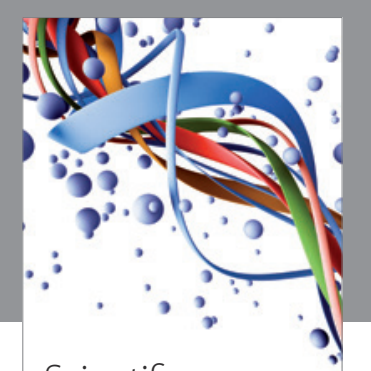

Scientifica
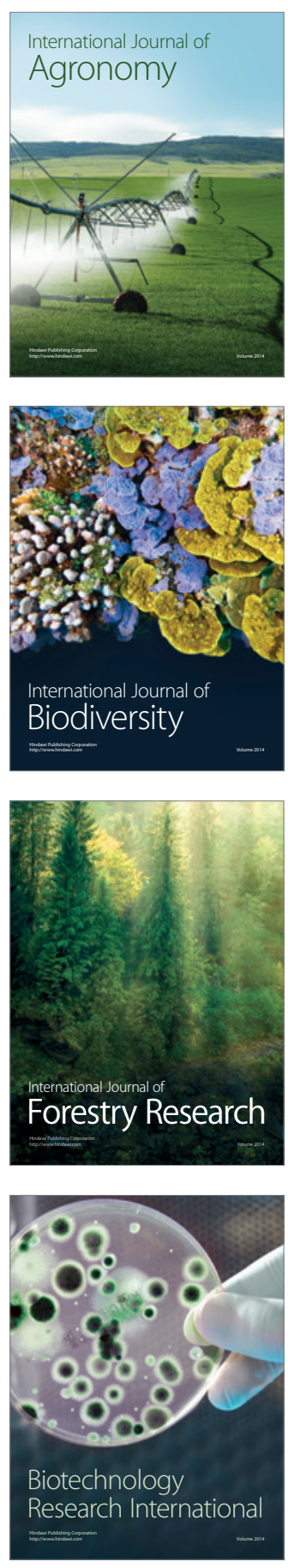
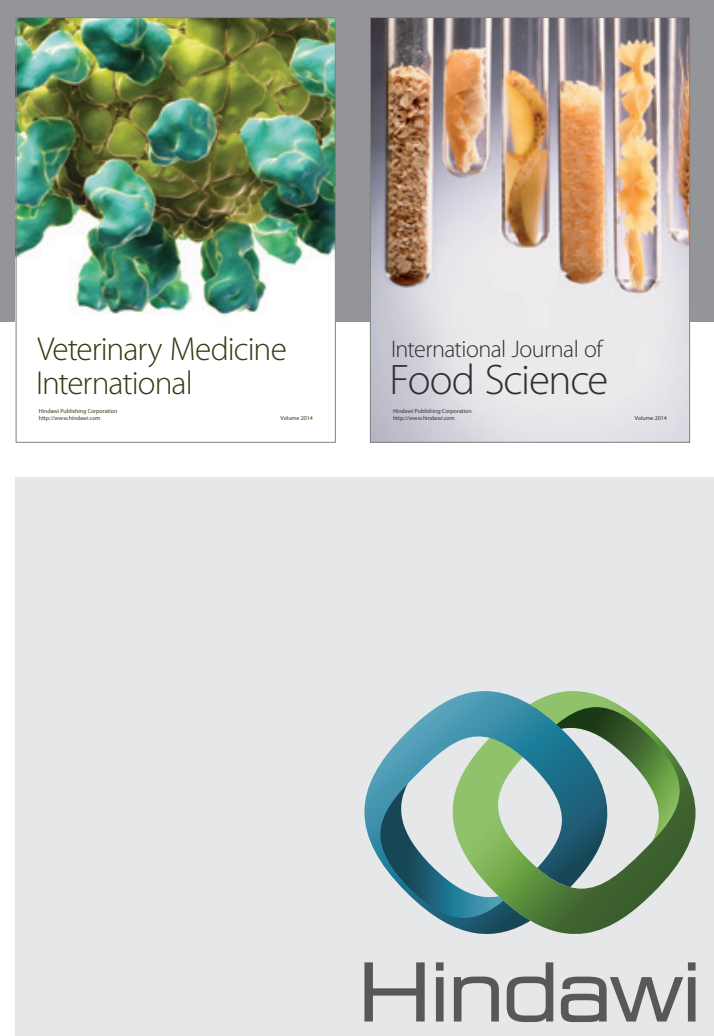

Submit your manuscripts at

http://www.hindawi.com
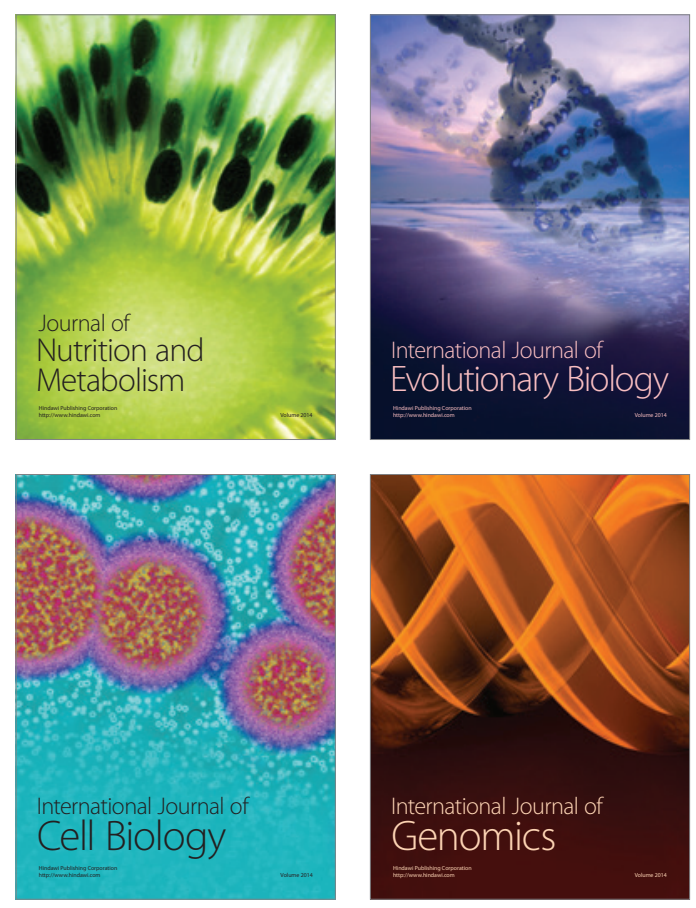
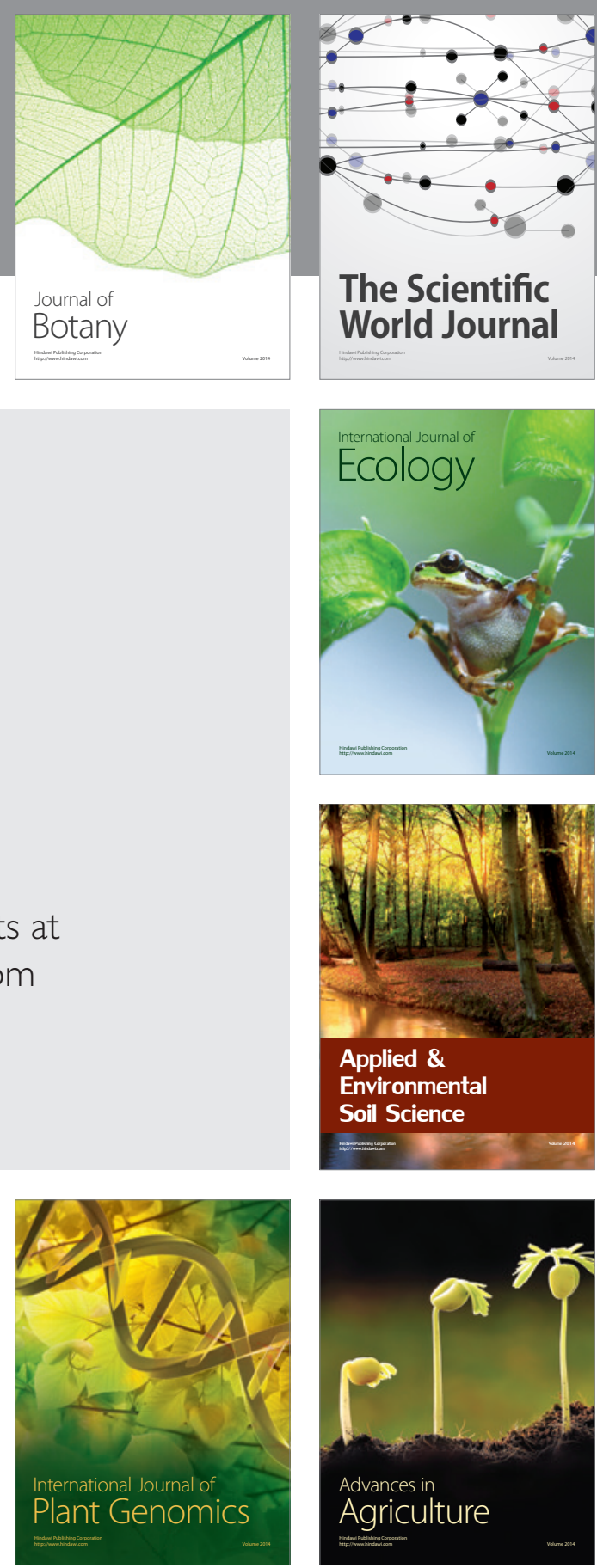

The Scientific World Journal
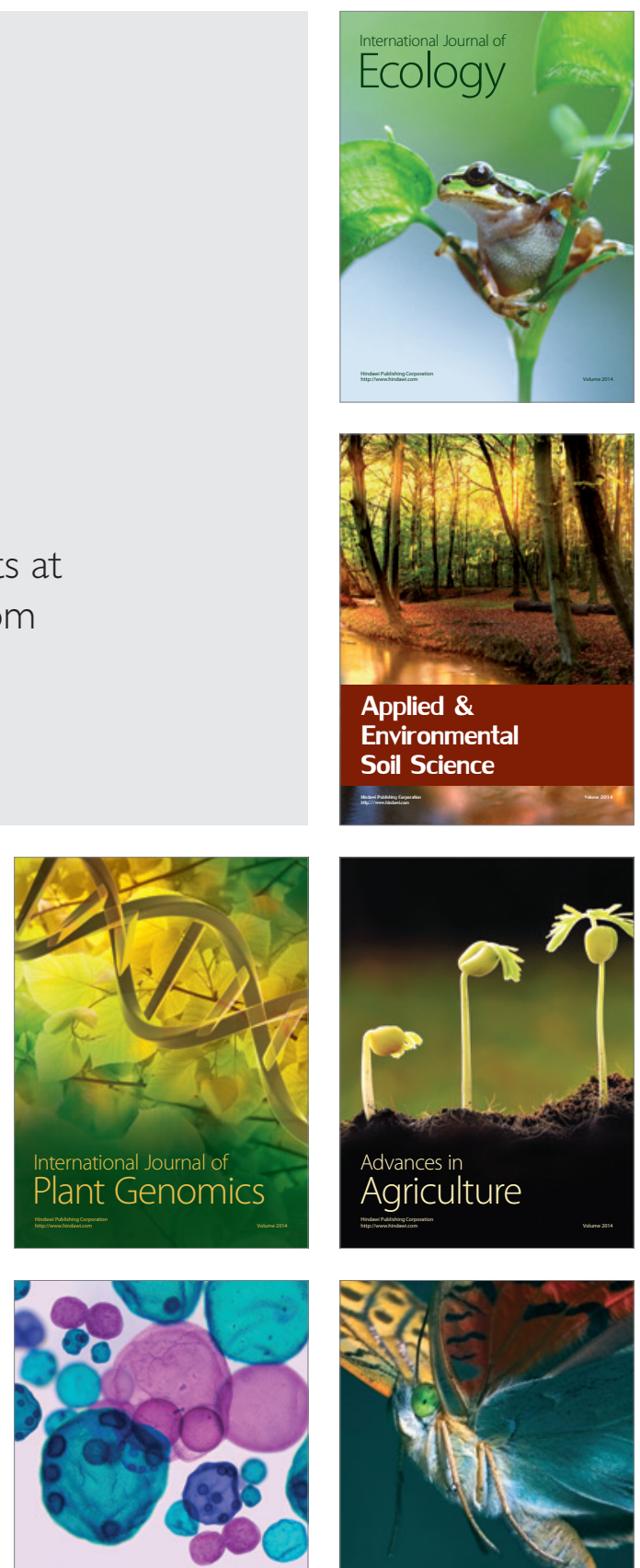

International Journal of Microbiology

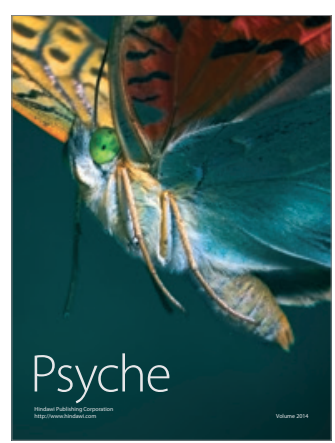

